\title{
Qualitative and Quantitative Comparative Review of Two Documentary Films on the Tuskegee Syphilis Study for Teaching Bioethics: Bad Blood
}

\section{vs. The Deadly Deception}

\section{Katz RV ${ }^{1 *}$, llin $D^{2}$, Katz $A E^{3}$, Cooper $K^{4}$, Haynes $A L^{5}$, Payne-Jackson $A^{6}$ and Shedlin MG $^{7}$}

${ }^{1}$ NYU College of Dentistry, ,USA and Social Sciences Program, NYU at Abu Dhabi, UAE

${ }^{2}$ Tisch School of the Arts at NYU, New York, USA

${ }^{3}$ Lecturer and Technical Manager of the Arts and Media, Film and New Media Program NYU at Abu Dhabi, Abu Dhabi, UAE

${ }^{4}$ Bioethics and Science teacher, Biomedical Ethics Program, Townsend Harris High School for the Humanities, Queens, New York, USA

${ }^{5}$ Department of Behavioral Sciences and Health Promotion, New York Medical College, New York, USA

${ }^{6}$ Department of Sociology and Anthropology, Howard University, Washington, USA

${ }^{7}$ Medical Anthropology, NYU Rory Meyers College of Nursing, New York, USA

\begin{abstract}
Objective: The purpose of this review was to identify teaching materials that would aid teachers in discussions with students about biomedical ethics using the infamous Tuskegee Syphilis Study as the case study.

Methods: A comparative qualitative and quantitative analysis of the two leading documentary films about the Tuskegee Syphilis Study (Bad Blood and The Deadly Deception) were conducted by seven individuals, spanning the diverse disciplines of sociology, anthropology, film making, bioethics and epidemiology. The qualitative comparative reviews were written by six of the co-authors spanning four social science disciplines and two film makers. The quantitative comparative assessment was done by two of the co-authors who first calibrated then recorded the exact film time within seven identified types of film footage segments for each of the two films.

Results: This first-ever comparative review of these two best-known documentary films on the USPHS Syphilis Study at Tuskegee revealed that five of the six qualitative reviewers selected Bad Blood as the superior documentary film over The Deadly Deception. Findings from the quantified analysis of the two films revealed that, despite being of the same overall length of time, The Deadly Deception contained 88 times segments vs60 timed segments for Bad Blood resulting in a film that appeared more disjointed, i.e., The Deadly Deception not only had a markedly shorter mean time per segment, but also used short film segments ( $<20$ seconds) twice as often as did Bad Blood. Overall, the detailed quantitative analysis of the film footage identified several factors that plausibly explained the near-unanimous selection of Bad Blood over The Deadly Deception as a superior teaching film.
\end{abstract}

Conclusion: The reviewers concluded that Bad Blood would better predict to lead to superior engagement of the viewing students in an active and highly desirable educational process of self-reflection and drawing of conclusions.

Keywords: Bioethics; Scientific misconduct; Teaching materials

\section{Introduction}

"The metaphoric phrase 'sin sick soul'...emphasizes the healing process necessary to reframe the tragedy of the USPHS Syphilis Study at Tuskegee into an opportunity for social justice....Surely, within its cultural context and content, the legacy of the USPHS Syphilis Study at Tuskegee is in the root of the history present and future of African Americans and all people of good well..." [1] - by Rueben C. Warren, Director, National Center for Bioethics in Research and Health Care at Tuskegee University.

"The legacy of the "Tuskegee" Syphilis Study is entwined in beliefs about racism and scientific/clinical hubris that are often deficient in factual understandings of the Study itself...The increasingly iconic status of the Study makes it what French historian Pierre Nora calls a "lieu de memoire," a site of memory....an interaction between history and memory, an event or experience, imagined and factual at the same time. The creation of a site of memory becomes the way in which individuals and groups in societies make meanings of their experiences and history" [2] - by Susan M. Reverby, Nursing Historian, Professor, Wellesley College.

"Thirty years have passed since I published 'Bad Blood', and I still have not taken my leave of Nurse Rivers. In my book's acknowledgements, I confessed that pondering her life had increased my tolerance for moral ambiguity and had helped me to understand why good people sin. To this day, she haunts me" [3] - by James H. Jones, American Social and Intellectual Historian, Professor Emeritus, University of Arkansas

"Bad Blood: The Tuskegee Syphilis Experiment [by James Jones] is the single most important book ever written in bioethics" [4].

"The revelation of the Tuskegee syphilis experiment in 1972...fueled the explosions of interest in bioethics in the U.S., which subsequently spilled over into Europe and the rest of the world" [4].

"Tuskegee gave birth to modern bioethics and James H. Jones was the midwife" [4] - all three by Arthur L. Caplan, Bioethicist and Director, Division of Medical Ethics, Professor, NYU School of Medicine.

*Corresponding author: Katz RV, Department of Epidemiology and Health Promotion, NYU College of Dentistry and Social Sciences Program, New York, USA, Tel: +212-998-9550; E-mail: ralph.katz@nyu.edu

Received November 15, 2018; Accepted November 20, 2018; Published November 27, 2018

Citation: Katz RV, Ilin D, Katz AE, Cooper K, Haynes AL, et al. (2018) Qualitative and Quantitative Comparative Review of Two Documentary Films on the Tuskegee Syphilis Study for Teaching Bioethics: Bad Blood vs. The Deadly Deception. Arts Social Sci J 9: 420. doi: 10.4172/2151-6200.1000420

Copyright: ( 2018 Katz RV, et al. This is an open-access article distributed under the terms of the Creative Commons Attribution License, which permits unrestricted use, distribution, and reproduction in any medium, provided the original author and source are credited. 
Citation: Katz RV, Ilin D, Katz AE, Cooper K, Haynes AL, et al. (2018) Qualitative and Quantitative Comparative Review of Two Documentary Films on the Tuskegee Syphilis Study for Teaching Bioethics: Bad Blood vs. The Deadly Deception. Arts Social Sci J 9: 420. doi: 10.4172/21516200.1000420

Page 2 of 7

Just how does one approach teaching 'something so big'...'so important'....'so very vital to becoming a good member of society'...so 'very vital to even having a worthwhile society'? To meet this challenge we need minimally to inundate all the senses of our students. We need to capture their attention, to first overwhelm and confuse their minds, and then to allow them time and space to find their own resolution of 'the issues'.

Several films on the infamous Tuskegee Syphilis Study, as conducted by the United States Public Health Service, have been made subsequent to the 1981 publication of James Jones' Bad Blood, universally acknowledged as the definitive history book of that infamous study. The three best known films made about the Tuskegee Syphilis Study include two documentary films (Bad Blood by Diverse Productions, Ltd and The Deadly Deception by Nova, and a 1997 HBO fictionalized film Miss Evers' Boys, based upon the 1992 play of the same name written by David Feldshuh $[5,6]$. The HBO fictionalize film Miss Evers Boys is undoubtedly the most widely viewed film version of this infamous USPHS Syphilis Study at Tuskegee (aka: the Tuskegee Syphilis Study) and was even recommended on the recommended list of films and books used in the Bioethics Teaching in Secondary Education (Project BEST), as developed jointly by the US Northwest Association for Biomedical Research and the Council of Europe to promote the teaching of bioethics in secondary schools [7]. Unfortunately, this $\mathrm{HBO}$ version of this infamous research study has several fictionalized elements, while both the other two best known films (Bad Blood and The Deadly Deception) are factually and historically correct in their presentation of content and therefore are likely superior for the teaching of bioethics to secondary school students.

To aid teachers in their discussions with students about ethics in general, and biomedical ethics in particular, we took on the task of conducting a comparative review of the two leading documentary films that have been made about the USPHS Syphilis Study at Tuskegee: Bad Blood by Diverse Productions, Ltd and The Deadly Deception by NOVA.

\section{Methods}

In order to ensure that this comparative review of these two documentary films (The Deadly Deception and Bad Blood) would encompass a broad and differing set of perspectives, the lead authors (RVK, DI, and AEK) invited four other individuals each with different, but relevant, professional training and with widely differing teaching experiences to contribute a comparative review of these two documentary films which addressed the issues and players involved in the United States Public Health Service (USPHS). Syphilis Study at Tuskegee, aka: the Tuskegee Syphilis Study.

The authors consist, then, of an award winning high school medical bioethics teacher and a university student majoring in film to contribute to this comparative review, as well as faculty spanning diverse university disciplines, namely sociology, anthropology, film making and epidemiology. This assemblage has taught in differing professional training schools, including medicine, public health, nursing and dentistry in addition to social science graduate school programs, college students and high school students. The contributing authors ranged in experience and age from one with $40+$ years of academic experience aged 72 to a $1^{\text {st }}$ year college student majoring in film aged 18 years, with the rest being at some in-between point in their lives.

Six of them were asked to write a completely independent qualitative comparative review of the two documentary films of at least 500 words with goal of making a comparison to answer the question: "Which one of these two films would you choose to use to teach bioethics to high school students?" The reviewers providing the qualitative reviews never saw the quantitative review prior to writing their qualitative review. Their comparative qualitative reviews were then edited to focus on each reviewer's primary points of emphasis and to eliminate unnecessary redundancy between reviewers.

Two of the authors (RVK and DI) then independently timed all the segments within each of the two films, quantitatively comparing results of both 'segment identification' and of the exact time for each segment, resolving any differences by discussion and-or re-timing. The eight page data collection sheet used for each film for this 'segment identification' and exact timing of each identified segment consisted pages 1-7 each having space to record 15 timed segments for seven 'segment identified' columns: Survivor Talking, Expert or Authority Talking, Presenter alone on screen, Presenter talking over archival scenes, Miss Ever's Play footage, Tuskegee footage with voice over, and Tuskegee footage only with music. These seven 'segment identified' columns were developed and agreed upon after the two lead authors had viewed each film one time. The eighth and last page in these data collection sheets was designed to allow tallying the overall total of the timed segments for the eight columns by page.

\section{What then, actually, is a documentary film?}

Before going into the comparative reviews of these two documentary films, it is crucial to understand what the purpose of a documentary film is and how documentaries differ from feature films. According to Bill Nichols' book Introduction to Documentary, "What actually counts as a documentary remains fluid, open to debate across institutions, filmmakers, audiences, and the films themselves [8]. It remains common today to revert to some version of John Grierson's definition of documentary, first proposed in the 1930s, as the "creative treatment of actuality" [9]. By modifying the commonsense definitions of documentary film, Nichols proposed the following as the 'best definition':

"Documentary film speaks about situations and events involving real people (social actors) who present themselves to us as themselves in stories that convey a plausible proposal about, or perspective on, the lives, situations, and events portrayed. The distinct point of view of the filmmaker shapes this story into a way of seeing the historical world directly rather than into a fictional allegory" [10].

Table 1 shows these two films, The Deadly Deception and Bad Blood, as comparatively categorized and ranked (via collaboration by the two contributing authors who are film makers: AEK and DI) using the simplified and adapted Documentary Model as proposed in Nichols' Introduction to Documentary book [8]. While there are several similarities observed between the two films both in the categorization and comparative ranking, Bad Blood was judged to be 'stronger' on its Expository Model and Poetic Model traits.

\section{Six Qualitative Comparative Reviews of the Two Documentary Films}

\section{Review \#1: by a film-maker who teaches film-making at university level}

Viewing Bad Blood and The Deadly Deception together is an interesting study of filmmaking, point of view and perspective, and illuminates 'what an audience seeks' when they commit to hearing a story. Both documentaries share similarities: the story, the main 
Citation: Katz RV, Ilin D, Katz AE, Cooper K, Haynes AL, et al. (2018) Qualitative and Quantitative Comparative Review of Two Documentary Films on the Tuskegee Syphilis Study for Teaching Bioethics: Bad Blood vs. The Deadly Deception. Arts Social Sci J 9: 420. doi: 10.4172/21516200.1000420

Page 3 of 7

\begin{tabular}{|l|l|l|}
\hline $\begin{array}{l}\text { Documentary } \\
\text { Models }\end{array}$ & Definition & $\begin{array}{l}\text { The Deadly } \\
\text { Deception }\end{array}$ \\
\hline Expository Model & Speak directly to viewer with voice over & \\
\hline Poetic Model & Stress visual and acoustic rhymes, patterns and the overall forms & ++ \\
\hline Observational Model & Looks on social actors go about their lives as if the camera not present & ++ \\
\hline Participatory Model & $\begin{array}{l}\text { Film makers interact with social actors, participates in shaping what happens before camera, e.g., directly } \\
\text { interview subjects }\end{array}$ & ++ \\
\hline Reflexive Model & Calls attention to the conventions/methods of documentary film making \\
\hline Performance Model & $\begin{array}{l}\text { Emphasizes the expressive quality of the film maker's engagement with the film's subject; addresses the } \\
\text { audience in a vivid way }\end{array}$ & ++ \\
\hline *Four point ranking scale where: +: Weak ++: Moderate $+++:$ Strong, and blank: Nonexistent \\
\hline
\end{tabular}

Table 1: Categorization and comparatively ranking of the two films (The Deadly Deception and Bad Blood) into Nichols six classic Documentary Models.

subjects, both were produced and made in the same decade (1992 and 1993), both share similar aims to uncover the transgressions and abuses of power that occurred during the Tuskegee Syphilis Study, both use investigative journalistic techniques, and both share similar running times (about 55 minutes). But they also reveal subtle differences in approach, technique and ultimately attitude and strategy that result in a different audience experience.

The Deadly Deception opens with an intellectual, journalistic and 'authoritative voice' that of George Strait. He drives into the unknown geography and story of the USPHS Syphilis Study at Tuskegee. In effect, his questions are our questions and his exploration mirrors the audience's. His voice-over is detailed, passionate but firm. It has the intonation and trained inflection of a traditional American TV reporter...Emphasis seems to be on the facts, uncovering the 'slippery slope' of government bureaucratic thinking, and how it led to one of the most infamous cases of public health work in US history...

Like The Deadly Deception, Bad Blood opens in the present day, with one of the study's victims, Anderson Sinclair, receiving medical care. However, the film quickly sets itself apart as it delves directly into the controversial study, with less 'set-up,' fewer facts, and less historical 'backdrop' than in The Deadly Deception. It establishes the subjects quickly, with intimate and real moments with the study subjects themselves. The camera work is more intimate and the audio allows moments to 'happen naturally'...The subjects are allowed a fuller life in this piece they are given their own voice, and speak and reflect in a more generous space from the filmmakers.

The voice-over is far more limited in Bad Blood, used sparsely throughout the piece as 'connective bridges' but lacking the instructive and more paternalistic voice-over in The Deadly Deception. Bad Blood is carefully curated extraneous or non-essential detail and facts are forgone in favor of emotion, pacing, and the audience being 'present' in the interviews, the city of Tuskegee (e.g. the 'city night montage' sequence), and with the victims of a study that clearly impacted them. Even the camerawork is more emotive - allowing for a more 'cinematic' experience with less of the TV 'talking heads' and news hour reporting camera techniques found in The Deadly Deception.

...Bad Blood is... an example of the filmmaker's rule of 'shows don't tell.' In its journalistic thoroughness, The Deadly Deception falls into the trap of clinical detachment. The filmmakers of Bad Blood freed themselves and through the nuances of the editing, the time spent with the subjects, and with the images of their world (both past and present) created a more compelling story, with more emotional impact on the audience.

Unlike The Deadly Deception, the filmmakers of Bad Blood allow the audience to draw their own conclusions and reactions more independently. Bad Blood leads us to an equally strong conclusion
- that is more our own, without the voices and experts' instruction. The film feels more organic as it allows the audience to ponder and experience the impact the study had on the lives of these men.

...As a teaching tool in the classroom, author believes Bad Blood would make a more refined instrument to teach bioethics. He think the film would have a longer lasting effect on students as they face their own moral and ethical decisions in the future...

\section{Review \#2: by a film-making college student majoring in film}

...Both documentaries chronicle the forty-year study of untreated syphilis in African American men from Macon County, Alabama, however, using different documentary techniques. The Deadly Deception has a visible narrator/presenter on the screen to tell about the occurrences, while Bad Blood uses the so-called 'voice of authority' approach, also named as 'voice of god' (i.e. a disembodied authoritative voice-over) [11]. So while in the former 'voice over' technique "[well-known political figures, respected celebrities, and actors with commanding vocal qualities may be employed to narrate [the film]" to impress the audience, it pales in authoritative impact in comparison to everything said by the 'voice of god' narration, which is more apt to be humbly accepted as truth by the audience [11].

...For the most part, The Deadly Deception uses 'talking heads' to emphasize how "the lives of these men did not count" and that "this was not some mad scientist in the basement doing this". Bad Blood, however, uses the same talking heads technique first to explain how the story of the USPHS Syphilis Study at Tuskegee broke out to the wider audiences and then to give more information about the study throughout the whole film in general.

This difference in 'talking heads' is one of the reasons why these two films hit their viewers differently. The Deadly Deception is more concerned with the feelings and emotions of the survivors of the Tuskegee Syphilis Study... Bad Blood, however, having more interview time of public health officials and historians, in the end reminds the viewer that the documentary is as much about the incredibly racist study as it is about the life story of the African-Americans who survived it.

Essentially, both films use the same evidence and even interview the same people; however, the ways in which the two films frame and contextualize evidence differ: Bad Blood is more educational and objective due to the off-screen voice over archival footage and a lot of interviews of public health officials...

...Based on everything above, we believe that Bad Blood is the better documentary to teach bioethics as it includes more in-depth interviews with public health officials as well as with the survivors of the study.... Bad Blood [is] a more saturated film. It achieves this by layering beautiful thought-provoking Delta blues music over Tuskegee 
Citation: Katz RV, Ilin D, Katz AE, Cooper K, Haynes AL, et al. (2018) Qualitative and Quantitative Comparative Review of Two Documentary Films on the Tuskegee Syphilis Study for Teaching Bioethics: Bad Blood vs. The Deadly Deception. Arts Social Sci J 9: 420. doi: 10.4172/21516200.1000420

Page 4 of 7

footage at several points in the film. These fragments with music over the county footage give the viewer time to digest the thoughts that are provoked by both the interviews and the archival footage with voice over....

\section{Review \#3: by a sociologist who teaches medical sociology in a medical school}

Instructional material developed for high school students about the meaning and significance of bioethics should address the basic principles used to guide judgments about human participant research including respect, beneficence, and justice. The material should situate ethical decision-making and investigative processes within the context of the broader social structure and the intersection of major social institutions such as medical, political, economic, religious, family, education, and legal...

Compared to Bad Blood, The Deadly Deception would provide better understanding of the intersection of major social institutions; culture, group membership, and symbolism; and the patient-provider relationship in terms of communication, power, and reciprocity. This film also provides clear examples of the violation of autonomy, benefit, and justice for the men involved....Although Bad Blood does highlight the invisibility of the systems of oppression; it fails to provide a full picture of the intersectionality of major social institutions that work, in tandem, to either hinder or support ethical decision-making in biomedical research. The Deadly Deception the power imbalances and task-driven approaches that are typical of the patient-provider relationship. The film also illustrates the concept of research burden and its social costs. The Deadly Deception stresses the three basic ethical principles that have become a normative framework of biomedical research and it underscores the fact that ethical decision-making does not take place in a vacuum. These factors would be critical for high school students to grasp as they learn about value and moral judgments in human participant research.

\section{Review \#4: by a cultural anthropologist who teaches anthropology at the university level}

Deadly Deception and Bad Blood are two documentaries made about the United States Public Health Service Study of Untreated Syphilis in the Negro Male. The question to be answered was which of the two documentaries is most appropriate for a bioethics class at the high school level....Bad Blood was ...the most suitable for high school students as it went directly to the point of what the documentary was about. The men who were victims of the Study provided insight into the devastating impact of the Study on their lives and the lives of the others. It revealed the bewilderment they felt that anyone, especially government and local doctors, would do such a thing to another human being.

Deadly Deception was ...too slow paced and meandering and more likely to lose the attention of students. It also was seen as providing a less in-depth understanding of the Study and its actual impact on the lives of those who were victims of the horrific experiment.

Bad Blood developed the story of the Study in a more direct focused format.. The devastating impact of the Study on the lives of the men was revealed in their own words and not merely as punctuation to scenes from a play... The denial by one of the medical personnel that the Study didn't "cause anyone harm" and that the study was for the "greater good" brought home the hypocrisy and perverted logic of the doctors involved in the Study. The direct focused approach used in Bad Blood is more likely to keep the attention of the students as first-hand accounts and actual voices are far more powerful in telling the story.

\section{Review \#5: by a medical anthropologist who teaches in a nursing college}

Teaching by storytelling is probably close to universal, at the family level as well as, for example, curricula which include "stories" (history, background, etc.) inherent in the case studies used in medical, public health, and social work schools...

The two films which tell the story of the USPHS Syphilis Study at Tuskegee clearly have a similar objective, to educate an audience about the study, and to raise issues of scientific/public health imperatives vs. social justice and human rights. Both present the historical and political issues and contrast (to different degrees) the moral and ethical stances of the medical and policy players, those who were involved and those who excuse or judge in another era. Both films use interviews with survivors, but to a different extent and style of editing....the major differences are not in content but rather in presentation.

Deadly Deception...tells the story with interviews and commentaries. The investigative reporting style is clear and thus emphasizes credibility. The medical history approach is dominant, and Cutler is as heinous in the clips as are his ideas and excuses. Visually it is basic, a historical documentary...

Bad Blood, on the other hand, uses dramatic musical and visual elements to bring the viewer into the story, to describe the context of the men's lives and the era visually...the rural area, the poverty, the gravestones, the deserted hospital...old footage of the clan, civil rights protests, abuses. The drama created by the interplay of interviews, film footage, photography and music tell the story in a different way, pulling the audience in to the reality of the era of paternalism and "benign racism" (!) acknowledged by white doctors...I believe the understanding and emotional response elicited by the presentation of the "story" in Bad Blood is a more effective vehicle for discussions of the biases of any historical reporting of an era, of the relativity of moral judgments, and the human rights and bioethical issues which deserve attention and memory.

\section{Review \#6: by a teacher of biomedical ethics in a magnet high school for the humanities}

When viewing the two documentaries, one is immediately struck by the stark contrast they present on the same topic. Bad Blood is the calm retelling of the story by many of the people directly involved, namely more of the survivors. Its goal seems to be to tell their story in their words, and from the point of the doctors involved in the study, but to remain as neutral as possible and allow the viewer to use the ideas presented to make their own opinions. The way the story highlights the role of the registered nurse Rivers is rather interesting, showing the way she built a relationship with the participants and their families to help the study, and, as those involved so passionately stated, to help those with syphilis.

Everything about The Deadly Deception screams Hollywood and drama. From the people they chose to interview, including the lawyer who represented the men involved in the study, to the narrator, the message of the creators is very clear - the study was wrong and nothing of value came from it Only when students can learn to formulate a solid opinion that can be supported by facts can they begin to discover the complexities presented by the issues discussed in the biomedical ethics classroom and engage in truly productive discussions and debates. We encourage our students to be passionate, but also to be level-headed 
Citation: Katz RV, Ilin D, Katz AE, Cooper K, Haynes AL, et al. (2018) Qualitative and Quantitative Comparative Review of Two Documentary Films on the Tuskegee Syphilis Study for Teaching Bioethics: Bad Blood vs. The Deadly Deception. Arts Social Sci J 9: 420. doi: 10.4172/21516200.1000420

Page 5 of 7

enough to be heard...If time only allowed for the use of one of the documentaries, we would use Bad Blood, because it would fit into a standard lesson with greater ease and allow the students to create their opinion with less of the bias that was evident in the other documentary

Note: Table 2 presents a summary of these six qualitative reviews and shows that 5 of the 6 reviewers selected Bad Blood as the superior choice for the teaching of bioethics to high school students. While teaching value was generally judged to be present in both documentary films, both film-makers and both anthropologists chose Bad Blood as the superior choice while the lone vote for The Deadly Deception was cast by the medical sociologist. Perhaps most tellingly, the high school teacher of biomedical ethics also selected Bad Blood as the superior documentary film for use with high school students.

\section{Quantitative Comparative Analysis of the Two Documentary Films and Its Impact on Judgments}

\section{Timed segments of the two documentary films}

The comparative findings from the timing of the identified seven types of film footage segments for each of the two films are presented in Table 3. As can be seen, Bad Blood not only used fewer types of film segments than did The Deadly Deception (5 vs6), Bad Blood also displayed a fairly even distribution of time $(\sim 24 \%)$ in each of four types of segments with only $4.5 \%$ in the fifth type of segment. On the other hand, The Deadly Deception had nearly half of its total time (47.6\%) dedicated to the 'Presenter' talking, either alone on the screen or with archival shots' (vs Bad Blood using less than half of that time for this type of segment). Finally, Bad Blood dedicated nearly 5 -fold more time to the Survivors talking type of segment than did The Deadly Deception (21.9\% vs $4.5 \%$, respectively).

Table 4, which looks at 'timed segments' from a more 'pure time' viewpoint (sans consideration of content focused upon) points out a clear difference in film making and film editing style between Bad Blood and The Deadly Deception. First, it should be noted that the two films are of nearly equal length: Bad Blood runs 50 minutes and 35 seconds, while The Deadly Deception runs 39 seconds longer at 51 minutes and 14 seconds. While both films had the same range of time per segment tally (4-5 seconds up to 183-186 seconds), The Deadly Deception was

\begin{tabular}{|c|c|c|}
\hline Reviewer Expertise & Key Review Comments & Final Choice \\
\hline \multirow[t]{5}{*}{ Filmmaker Teaching Film at university level } & TDD emphasis is on the facts, less emotion & \multirow[t]{5}{*}{ Bad Blood } \\
\hline & TDD voice-over use is far more paternalistic & \\
\hline & BB focus on emotion, pacing, more cinematic & \\
\hline & BB allows audience to draw own conclusions & \\
\hline & BB follows rule of 'show don't tell' & \\
\hline \multirow[t]{5}{*}{ Filmmaking students major in university level } & BB uses very strong and metaphoric visual imagery & \multirow[t]{5}{*}{ Bad Blood } \\
\hline & BB uses stronger 'voice of god' voice-over technique & \\
\hline & TDD feels more like a mere educational documentary & \\
\hline & BB layers thought-provoking blues music over scenes & \\
\hline & BB feels more like a more saturated film & \\
\hline \multirow{5}{*}{$\begin{array}{l}\text { Sociologist teaching medical sociology at medical } \\
\text { school }\end{array}$} & BB focuses more on power-based differences by group & \multirow{5}{*}{$\begin{array}{l}\text { The Deadly } \\
\text { Deception }\end{array}$} \\
\hline & TDD stronger on interplay of major social institutions & \\
\hline & TDD gives clearer examples of autonomy, benefit, justice & \\
\hline & TDD focuses on concept of research burden & \\
\hline & TDD stresses ethical behaviour does not occur in a vacuum & \\
\hline \multirow[t]{5}{*}{ Cultural Anthropologist teaching at university level } & BB focused more on the bewilderment of the subjects & \multirow[t]{5}{*}{ Bad Blood } \\
\hline & TDD was too slow and meandering to command attention & \\
\hline & TDD news clips drew attention away from theme of film & \\
\hline & BB news clips more directly related to the theme of film & \\
\hline & BB stronger use of actual subject voices is more powerful & \\
\hline \multirow[t]{5}{*}{ Medical anthropologist teaching at nursing level } & Major difference is not in content but presentation & \multirow[t]{5}{*}{ Bad Blood } \\
\hline & TDD uses medical history approach but visually is basic & \\
\hline & BB uses dramatic musical and visual elements & \\
\hline & BB pulls viewer into era of paternalism \& "benign racism & \\
\hline & BB pulls viewer into era of paternalism \& "benign racism & \\
\hline \multirow{5}{*}{$\begin{array}{l}\text { Biomedical ethics teacher at a humanities-focused } \\
\text { magnet high school }\end{array}$} & BB is a calm retelling of story by the subjects themselves & \multirow[t]{5}{*}{ Bad Blood } \\
\hline & BB allows use of ideas presented to form one's opinions & \\
\hline & TDD screams Hollywood and drama & \\
\hline & TDD inclusion of the lawyer provides interesting insight & \\
\hline & BB allows students to create their own opinion, less biased & \\
\hline
\end{tabular}

Table 2: Summary of 6 comparative reviews on The Deadly Deception (TDD) vs. Bad Blood (BB) documentary films as the 'better choice' for the teaching of bioethics to high school students.

\begin{tabular}{|c|c|c|c|c|c|c|c|}
\hline Film & $\begin{array}{c}\text { Survivor } \\
\text { talking }\end{array}$ & $\begin{array}{c}\text { Authority } \\
\text { talking }\end{array}$ & $\begin{array}{c}\text { Presenter alone on } \\
\text { screen }\end{array}$ & $\begin{array}{c}\text { Presenter with } \\
\text { archival shoots }\end{array}$ & $\begin{array}{c}\text { Miss Ever's } \\
\text { play footage }\end{array}$ & With voiceover & Wuskegee footage \\
\hline Deadly Deception & $4.50 \%$ & $29.20 \%$ & $6.20 \%$ & $41.40 \%$ & $8.00 \%$ & $10.70 \%$ \\
\hline Bad Blood & $21.90 \%$ & $29.80 \%$ & - & $20.90 \%$ & & $22.90 \%$ \\
\hline
\end{tabular}

Table 3: Comparative distribution of timed film footage segments across 7 segment categories for the deadly deception vs. bad blood. 
Citation: Katz RV, Ilin D, Katz AE, Cooper K, Haynes AL, et al. (2018) Qualitative and Quantitative Comparative Review of Two Documentary Films on the Tuskegee Syphilis Study for Teaching Bioethics: Bad Blood vs. The Deadly Deception. Arts Social Sci J 9: 420. doi: 10.4172/21516200.1000420

Page 6 of 7

\begin{tabular}{|c|c|c|c|c|c|c|}
\hline & The deadly deception & & & Bad blood & & \\
\hline & (\# of timed segments=88) & & & (\# of timed segments=60) & & \\
\hline $\begin{array}{l}\text { Length of time } \\
\text { categories }\end{array}$ & Count of Footage segments & $\begin{array}{c}\% \text { of total Footage } \\
\text { segments }\end{array}$ & & Count of Footage segments & $\begin{array}{c}\% \text { of total Footage } \\
\text { segments }\end{array}$ & \\
\hline $0-9 \mathrm{~s}$ & 9 & $10.20 \%$ & & 3 & $5 \%$ & \\
\hline $10-19 \mathrm{~s}$ & 24 & $27.30 \%$ & & 8 & $13.30 \%$ & \\
\hline $0-19 \mathrm{~s}$ & & & $37.50 \%$ & & & $18.30 \%$ \\
\hline $20-30 \mathrm{~s}$ & 19 & $21.60 \%$ & & 9 & $15.00 \%$ & \\
\hline $30-59 \mathrm{~s}$ & 22 & $25.00 \%$ & & 24 & $40.00 \%$ & \\
\hline $20-59 \mathrm{~s}$ & & & $46.50 \%$ & & & $55.00 \%$ \\
\hline $60-90 \mathrm{~s}$ & 10 & $11.40 \%$ & & 10 & $16.70 \%$ & \\
\hline $91-119 \mathrm{~s}$ & 1 & $1.10 \%$ & & 3 & $5.00 \%$ & \\
\hline $120-179 s$ & 2 & $2.30 \%$ & & 2 & $3.30 \%$ & \\
\hline $180-186 \mathrm{~s}$ & 1 & $1.10 \%$ & & 1 & $1.70 \%$ & \\
\hline $60-186 \mathrm{~s}$ & & & $15.90 \%$ & & & $26.70 \%$ \\
\hline Total & 88 segments & $100 \%$ & $100 \%$ & 60 segments & $100 \%$ & $100 \%$ \\
\hline $\begin{array}{l}\text { Mean length of time } \\
\text { per segment: }\end{array}$ & $34.9 \mathrm{~s}$ & & & $50.6 \mathrm{~s}$ & & \\
\hline $\begin{array}{l}\text { Range of time per } \\
\text { segment }\end{array}$ & $5-183 s$ & & & $4-186 s$ & & \\
\hline
\end{tabular}

Table 4: Distribution of 'type of footage segments' by length of time with mean time and range of time for bad blood vs. the deadly deception.

comprised of 88 timed segments while Bad Blood had only 60 timed segments. This resulted in a markedly longer 'mean time per segment' for Bad Blood, i.e., 50.6 seconds per segment vs34.9 seconds for The Deadly Deception. Further, Table 3 shows short film segments $(<20$ seconds) were twice as frequently used in The Deadly Deception $(37.5 \%$ of the time vs $18.3 \%$ of the time in Bad Blood). Conversely, over a quarter of the film segments in Bad Blood lasted between 1-3 minutes as compared to only $16 \%$ of the film segments running this long.

Overall, then, despite the similar total running length of both films there were nearly $50 \%$ more film segments in the Deadly Deception (88 vs60) with the result that the mean film segment length (timed in seconds) is $45.2 \%$ longer for Bad Blood with about half the number of short $(<20$ second) film segments. Thus, the film segments in Bad Blood are fewer in number, but longer in running time.

\section{Impact of the Quantitative Data on the Qualitative Judgments: Plausible Thoughts}

While all six reviewers saw value in both films, their near unanimous judgment that Bad Blood was the superior documentary film to use for the teaching of bioethics to high school students seems to reflect more their positive reaction to the style of and presentation by the film-makers of Bad Blood, than to any difference in content per se (which they identified as very similar).

One strong theme evident across the reviewers was their observation that Bad Blood was clearly superior on the highly desirable 'teaching factor' of allowing the students to arrive at their own conclusions. This was specifically noted by both film-makers and the high school bioethics teacher, and hinted at by the medical anthropologist. This perceived effect was plausibly linked to quantitative data showing that Bad Blood was composed of fewer but longer 'mean time' film segments, thus allowing viewers to think more completely about the issues being presented. The data on this shows that over $25 \%$ of the film segments in Bad Blood lasted 1-3 minutes (only 16\% being of this length in The Deadly Deception) and conversely, Bad Blood had half as many very short ( $<20$ second) film segments as did The Deadly Deception. The high school bioethics teacher specifically noted that $\mathrm{Bad}$
Blood was 'less biased' in presentation and would allow the students to create their own opinions.

A second strong theme across the reviewers was their recognition that the Bad Blood combination of more time showing the subjects speaking and less time being lectured at by the on-screen presenter led to a more captivating film...more engaging, less pedantic. This was referred to by both film-makers, both anthropologists, and the high school bioethics teacher. The quantitative data on this shows that nearly half of the entire The Deadly Deception film consisted of the 'on-screen presenter' talking to the viewers (vs only $0 \%$ time in $\mathrm{Bad}$ Blood), and with $80 \%$ of that time consisting, literally, of only a talking head on screen without any archival shots as he spoke. Conversely, the quantitative data shows that Bad Blood dedicated nearly 5 -fold more time to the Survivors talking than did The Deadly Deception $(21.9 \%$ vs. $4.5 \%$, respectively).

Linking the two above strongly noted themes, it was also noted by most of the reviewers that the frequent use of 'thought-provoking Delta blues' music throughout Bad Blood especially over 'non-content' film footage only showing local scenes in the Tuskegee area encouraged students to reflect and to draw their own conclusions...judged by the reviewers to be a highly desirable element for the teaching of bioethics.

\section{Conclusion}

The USPHS Syphilis Study at Tuskegee, cited at its Wikipedia website as being "arguably the most infamous biomedical research study in U.S. history", is said to "fueled the explosions of interest in bioethics in the U.S., which subsequently spilled over into Europe and the rest of the world" $[4,12]$. As the most well-known example of a peacetime research atrocity, and as it unfolded over a very prolonged period of 40 -years, it is a story rich in lessons as much about life, about people and their actions, motivations and ambitions, and about institutions and their power, as it is about ethical behavior and bioethical standards. As such, it holds the promise to be a grand teaching example for the teaching of bioethics to future generations, so its invaluable lessons are neither unknown, nor overlooked, nor forgotten.

This qualitative and quantitative comparative review of the 
Citation: Katz RV, Ilin D, Katz AE, Cooper K, Haynes AL, et al. (2018) Qualitative and Quantitative Comparative Review of Two Documentary Films on the Tuskegee Syphilis Study for Teaching Bioethics: Bad Blood vs. The Deadly Deception. Arts Social Sci J 9: 420. doi: 10.4172/21516200.1000420

Page 7 of 7

two best known and produced documentary films on the subject of the USPHS Syphilis Study at Tuskegee was undertaken to provide guidance to teachers who wished to use this powerful historical tragedy of study to teach their students about ethics and bioethical practices and standards.....and how it can go so very wrong, for so very long.

This first-ever comparative review of these two best-known documentary films on the USPHS Syphilis Study at Tuskegee (aka: The Tuskegee Syphilis Study) revealed that five of the six qualitative reviewers selected Bad Blood as the superior documentary film over The Deadly Deception. Moreover, the quantitative analysis of the film footage, identified several factors that plausibly explained the near-unanimous selection of Bad Blood over The Deadly Deception as a superior teaching film, identifying such factors as longer length of timed film scene segments, fewer very short film scene segments, effective use of music, less timed use of taking narrator, more timed use of interviews with study subjects... all of which together collectively were judged to better predict for superior engagement of the viewing students in an active and highly desirable educational process of selfreflection and drawing of conclusions.

These comparative qualitative findings, supported by our quantitative analyses, on these two documentary films provides high school teachers of bioethics a frame for selecting the superior documentary film for purpose of teaching bioethics. While Project BEST listed the highly fictionalized HBO 'Miss Evers' Boys' film version in its list of recommended films and books [7], the poignant story of and lessons to-be-learned from the most infamous research abuse in U.S. history are more historically accurately revealed in either of these two documentary film versions (Bad Blood and The Deadly Deception) with Bad Blood being the favored choice by our multi-disciplined panel of reviewers.

\section{Funding}

Funding for this project was provided by the NYU at Abu Dhabi Faculty Research Fund.

\section{References}

1. Warren RC (2011) Healing the Sin Sick Soul: Reflections on the Syphilis Study. In: Katz RV, Warren RC (eds.) Searching for the Legacy of the USPHS Syphilis Study at Tuskegee, Lexington Books.

2. Reverby SM (2011) The "Tuskegee" Syphilis Study as a Site of Memory. In Katz RV, Warren RC (eds.) Searching for The Legacy of the USPHS Syphilis Study at Tuskegee, Lexington Books.

3. Jones JH (2011) Of Thanks and Forgiveness. In: Katz, RV, Warren RC (eds.) Searching for The Legacy of the USPHS Syphilis Study at Tuskegee, Lexington Books.

4. Caplan AL (2007) Books Forum: Bad Blood: the Tuskegee Syphilis Experiment Bio societies 2: 275-276.

5. Bad Blood (1992) Diverse Productions, Ltd, Channel Four (Great Britain), the Arts and Entertainment Network.

6. The Deadly Deception [1993] Nova WGBH Educational Foundation.

7. Araujo J, Gomes CC, Jacomo A (2017) Teaching bioethics in high schools Health Education Journal 76: 507-513.

8. Nichols BA (2010) Introduction to Documentary. Bloomington, Publisher: Indiana University Press; 2nd Edition, p: 142.

9. Eitzen D (1995) When is a Documentary? Documentary as a Mode of Reception. Cinema Journal 35: 81-102.

10. Nichols BB (2010) Introduction to Documentary. Bloomington, Publisher: Indiana University Press; 2nd Edition, p: 14.

11. Maria P, Wallis T (2011) Film: A Critical Introduction. London: King, Published by Pearson; 3rd Edition p: 283.

12. Katz RV, Kegeles SS, Kressin NR, Green BL, Wang MQ, et al. (2006) The Tuskegee Legacy Project: willingness of minorities to participate in biomedical research. J Health Care Poor Underserved 17: 698-715. 